Article

\title{
Environmental Aspects of Generation Y's Sustainable Mobility
}

\author{
Michał Suchanek * $*$ and Agnieszka Szmelter-Jarosz \\ Faculty of Economics, University of Gdańsk, 81-824 Sopot, Poland; a.szmelter@ug.edu.pl \\ * Correspondence: m.suchanek@ug.edu.pl; Tel.: +48-58-523-11-25
}

Received: 3 May 2019; Accepted: 5 June 2019; Published: 8 June 2019

check for updates

\begin{abstract}
This research paper identifies and explores the opinions and attitudes of young people about urban transport. It is the first study on this topic, based on the survey, analysing the mobility choices of young adults (more specifically, Generation Y) in Poland and for countries in Central and Eastern Europe. The aim of the paper is to show their travel behaviour from sustainable mobility perspective. The primary data was obtained through the online survey. The data analysis was held with use of factor analysis and ANOVA. The research results indicated the variables influencing the environmental dimension of sustainable mobility attitudes of young adults in four areas: the ecology-oriented approach to transport, opinions about sharing economy, public car concept and future transport system. The analysis of variance revealed significant differences in the ecology-oriented approach between people born in different decades, between men and women and between people with driving licences and people without them. Those results provide the insights for local authorities and mobility service providers. The recommendations at the end of the paper focus on the need for continuation of research in similar fields.
\end{abstract}

Keywords: generation y; millennials; urban mobility; sustainable transport; environment; city logistics; mobility patterns

\section{Introduction}

Growing cities and their populations have become a challenge for today's researchers, local authorities and business decision-makers. One of the problems troubling the current politics is meeting the requirements of sustainable transport, especially when urban residents present the opposite needs. The level of the air pollution, congestion traffic and lack of the accessibility of the public transport for the suburbs were at the basis of creation of the new order in cities, and the main tool for making that happen was the SUMP — sustainable urban mobility plan [1]. The urban transportation system is represented by various features: safety, accessibility, profitability, multimodality, integration, efficiency, sustainability and many others. As a result, mobility management has become one of the main areas of interest for local authorities and researchers.

Sustainability is the construct of three dimensions: economic, social and environmental. Within the urban logistics area, including urban transport, those dimensions can be addressed, among others, by behaviour of different stakeholders (residents, workers, tourists), in different age groups, preferring different lifestyles [2]. The objective of the transport system should be to improve the quality of life in the city and suburbs by ensuring a safe, reliable, integrated, multi-modal, effective and eco-friendly transport system (especially by using low-emission and zero-emission vehicles, park and ride solutions etc.) [1,3] It should be a result of an integrated approach to coordination and cooperation of different stakeholders, including the authorities, service providers and city users [4], also, by using benchmarking practices [5]. The range of possible solutions in the huge part relates to residents, workers and tourists, whose transport is dominated by private vehicles. Their eco-friendly transport 
attitudes are one of the elements of the environmental sustainability in the urban mobility [6]. They are one of the biggest road users groups in cities, therefore, their behaviour should be analysed.

The main objective of this paper is to explore the sustainable mobility attitudes of young people, especially its environmental elements, and check if they meet the general view of Generation $Y$ mobility patterns, described in the literature. To the best of the researchers' knowledge, there are only few papers related strictly to this topic. This paper provides initial insights into results of social changes in cities. As one of the first in the literature, it presents the sustainable mobility attitudes of one of the post-socialism nations in Central and Eastern Europe, the priorities and behaviour of which still differ from the other nations, living in Western Europe. Polish society is one of the fastest developing in the region, with big population and growing purchasing power. Therefore, the analysis for this country is important to understand the changes on the mobility market. This analysis can provide also managerial implications for local authorities, public transport operators and mobility service providers to adjust their offer and strategies to the needs of current and future customers on the Polish market.

The paper is organised as follows. The first section gives a review of the literature on the studied topic. The second part of the paper presents the methodology of the main research (survey), data collection and data analysis. In this study, the factor analysis and ANOVA were used. The use of those methods allowed for the detailed analysis of data described by nominal and ordinal scales. The third section contains research results. The study indicated few factors representing Y generation's attitudes: necessity for environmentally friendly transport, the shared mobility solutions, the city car systems and the future of car city systems in country. The analysis of variance revealed significant differences in the ecology-oriented approach between people born in different decades, between men and women and between those with driving licences and those without. The final section discusses the results, compares them with others, concludes the paper, presents its limitations and specifies areas for future research.

\section{Literature Review}

\subsection{Sustainable Urban Transport}

The sustainable urban transport, in many cities represented by the SUMPs, aims at, among others, improving the quality of life within the city, and also for the suburban zone, being an inseparable part of city life, connected to the centre by a network of transport lines. Involving the stakeholders into policy planning and integrating the functional policies (sector policies, such as safety policy, social policy, education policy, marketing policy and environmental policy) should create a good benchmark to achieve the goal [7-9]. The multi-actor approach causes a number of difficulties in planning activities because each stakeholder has different goals and requirements, so first steps in this procedure should be informing, consultation, open discussion and co-decision making [10,11].

The wide range of possible specific aims of urban transport should cover the economic, social and environmental dimensions of sustainability (see Figure 1). They are much related with each other. The most often discussed and described is the last one, concerning reducing travel-trip substitution (e.g., home office), the distance (e.g., combining living and shopping functions of new and old buildings), shifting modes (reducing private car use, promoting cycling and multimodality), decarbonisation (zero- or low-emission mobility) [12-15]. Those areas are addressed by the policy-makers to fulfil the assumptions of improving decarbonisation of cities [13]. Sharing economy is one of them, being a sustainable resource management, and at the same time, efficient assets management. Today over $70 \%$ of Europeans live in cities, and the whole economy loses 1\% of GDP every year because of congestion, and this is why urban mobility has to be optimised $[13,16]$. 


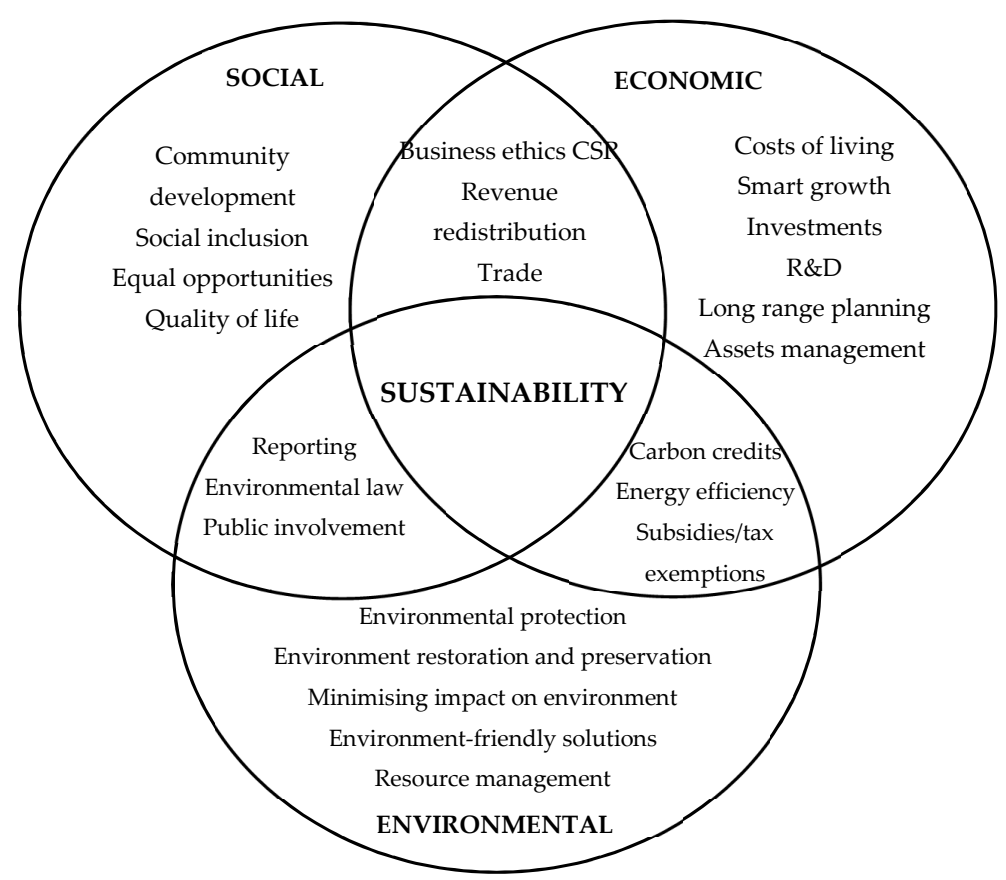

Figure 1. Dimensions of sustainable development. Source: [17].

New solutions for the mobility of people have been introduced mostly in cities. Among these solutions are free-floating and station-based car-sharing systems [18], integrated passenger transport system and shipping tariff [19], bus rapid transport, fare management integration, payment systems integration, smart cards systems, bike-sharing systems [20], prioritization of buses (dedicated lanes), park-and-ride facilities, public cars, development of pedestrian infrastructure [21,22], free-fare public transport [23] and many others.

According to Tilley and Houston [24], social and demographic changes may have a strong influence on mobility trends, especially in urban and suburban areas. There can be a wide range of determinants influencing such a trend, and also the environmental attitudes of urban residents, especially young ones $[2,24,25]$.

\subsection{Mobility Patterns}

Mobility pattern as a complex construct [6], is presented in the literature as the same concept as travel choices, travel behaviour, travel pattern and transportation lifestyle [26]. Mobility and travel studies regarding urban transport have been carried out since the middle of the 20th century but gained popularity in the last ten years. The history of travel behaviour from the late 1960s was presented in detail by Wittwer [27]. Besides, a broad description of the travel behaviour patterns was presented by Sigurdardottir et al. [28].

For the purpose of this study, and according to the studied literature items, we define the mobility pattern as the same construct as travel behaviour and as a group of variables influencing the choice of transport modes and means, both for commuting and non-commuting journeys. We define this set of variables as consisting of three areas, similar to those described for sustainability: economic, social and environmental [29]. The last of them is the main topic of this study.

The area of mobility studies is based on different fields of knowledge: logistics, economic geography, transport economics and spatial analysis. This interdisciplinarity causes many difficulties in preparing the complex study of the mobility patterns but also is a chance for combining the research of different specialists to create a reliable methodology to measure the mobility attitudes and choices. Notably, in the early studies about travel behaviour, the socio-demographics is under-emphasised and overlooked [30]. Nowadays, more research differentiates the mobility choices according to birth cohort, gender and belonging to identified socio-spatial groups [24]. Social factors, especially equality of men 
and women in the developed countries, lately also in developing ones, are taken into consideration in those studies [24,31]. People generally tend to acquire the mobility patterns from their parents and grandparents (socialisation on adult travel behaviour), and continue them in a natural way [32,33].

The conditions mentioned above constitute grounds for including social scientists and psychologists in mobility research. Therefore, the "mobility socialisation" direction in up-to-date literature is popular. This socialisation is defined as a process making the individual a part of the mobile society, in the area of terrestrial mobility. The result of this is the mobility lifestyle, called by us as the mobility pattern, the long-term mobility behaviour, also related to the mobility over the life course. The multi-dimensional set of important variables influencing the mobility demand have to be justified and their impact presented. Those variables depend on accessibility, lifestyle, childhood and many others [32].

The most popular in the current literature is the research made in urban areas. It is today represented by ca. $60 \%$ of the global society, with an expected value of approximately $70 \%$ in 2050 [34]. In Poland, the situation is the opposite-the number of people living in the city is getting lower every year, and the number of suburban residents is still growing, regardless of their age [34].

\subsection{Y Generation}

Generation Y (also called the Millennial generation, Millennials, Next Generation, iPod generation) is currently a mystery for socio-economic researchers [35]. It will also be described by us as young adults due to the fact that in many studies both concepts are used interchangeably [36-39]. It presents different attitudes, priorities and lifestyles than older cohorts, in different areas-work [18], home, commuting and travelling [40,41], which causes difficulties in marketing and seeking of employment.

There are many inaccuracies in defining the Y generation. Raunio [42] divides the whole Millennials group into few cohorts: Generation Why (1982-1985), middle-Millennials (1985-1999) and iGeneration (1999-2002), and the middle one presents the core values and opinions usually assigned to young adults. Some divide the Millennials into the younger (18-24) and older ones (25-35), but sometimes it does not correspond to the most popular approach to generational theory [43,44]. Generally, Millennials are people born between 1981 and 1999, characterised by the widespread adoption of new technologies, especially the internet, cell phones, and social networks, which have been hypothesised as influencing on young adults' mobility, among others, through using Mobility-as-a-Service services (for example Uber, Lyft) [45].

Some regularities can be observed in available research results. Older (Baby Boomers, the older part of the $X$ generation) and the youngest cohorts ( $Z$ generation) are usually less mobile than the people in their productive, prime age, which currently are the youngest people of the $X$ generation and the whole $Y$ generation. This is the result of their economic, work and social situation.

The gender differences in the mobility area were indicated in the research of Tilley and Houston [24]. Those were a result of multiplication of the women's roles in society (mothers going with children to school or kindergarten, housewives doing the shopping, part-time workers, full-time workers). Women travel more than men, for shorter distances, choose usually slower means of transport, more often active modes or public transport. The situation has changed between 2008 and 2016 and Generation Y women travel more than men in the same age. Young women also are more eco-friendly travellers than men [24,25].

There are also some researchers' voices negating the high activity of Generation $\mathrm{Y}$ in car mobility in cities and presenting a declining number of VKT (vehicle kilometres travelled) despite temporary short-term increases. What is more, Generation $Y$ have less driving licenses, drive less even if they own a car and use more alternative transport modes [29,36].

Using active modes of transport (also called soft modes), especially in cities was presented by Lopez-Carreiro and Monzon [37]. In addition, they often choose dense city areas to rent an apartment or buy one because of the possibility of using soft modes and having access to all shops and other facilities they need. However, it is still unclear if these motivations are caused by environmental 
concerns only, or not, even if it is important for them. It can be a result of struggling to live healthier than their parents and grandparents. Young people see their parents, grandparents and other older relatives are suffering from diseases caused by unhealthy lifestyles and are trying to avoid these problems when growing old themselves. What is more, they are more willing to live with parents or roommates, starting their families and having children later than older cohorts, so they can use the active modes longer $[29,46]$.

The mobility patterns were established to present particular needs and habits of different generations. Those identified for the $Y$ generation are Drivers, Long-distance Trekkers, Multimodals, and Car-less, also differentiated by the neighbourhood to assign the dominating patterns to particular city areas-city centre, districts and suburban zones [47]. The Drivers can be further divided (within the Y generation) into High-frequency commuters, Global Jest Setters, Greenovators and others [45].

\section{Methods}

\subsection{Survey}

The main research method was the survey method, an online survey containing standard layout (headline, main part, metric). The questions were modelled on the available interview sheets and questionnaires in the selected literature. The questions were divided into a few research areas, and one of those were related to the environmental attitudes of young people. The questionnaire contained mostly closed questions and scale questions examining the opinions, behaviour and attitudes of the surveyed persons. The pilot study preceded the main survey (within purposefully selected 42 people born in 1997), then the questionnaire was amended according to the comments of the pilot group. The main survey participants were recruited based on the inclusion criteria (semi-random sampling), which were the year of birth (1981-1999). Aggregated details for the research sample are presented in Table 1. During the data collection process, 437 fully filled questionnaires were obtained.

Table 1. Aggregated details for the research sample.

\begin{tabular}{|c|c|}
\hline Category & Result \\
\hline Year of birth & 1981-1989 19.2\%; 1990-1999 80.8\% \\
\hline Sex & Female $56.5 \%$; Male $43.5 \%$ \\
\hline Driver license & Yes $87.9 \%$; No $12.1 \%$ \\
\hline Own car & Yes $29.1 \%$; Someone else's car $28.6 \%$; Company car $2.3 \%$; No $40 \%$ \\
\hline Main means of transport & $\begin{array}{l}\text { Car 34.8\%; PT 55.6\% (Bus 21.5\%, Fast rail 22.7\%, Tram/trolley } 8.5 \% \text {, Rail } 2.7 \% \text {, Taxi } \\
0.2 \% \text { ), Active } 9.6 \% \text { (On foot } 8.2 \% \text {; Motorbike } 0.5 \% \text {, Bike } 0.9 \% \text { ) }\end{array}$ \\
\hline Using PT & $\begin{array}{l}\text { Every day } 50.1 \% \text {; } 2-3 \text { times a week } 18.8 \% \text {; Once a week } 7.1 \% \text {; Once a month } \\
10.1 \% \text {; Less than once a month } 10.1 \% \text {; At all } 3.9 \%\end{array}$ \\
\hline Student/employment status & $\begin{array}{l}\text { Bachelor students } 53.3 \% \text {; Master students } 9.8 \% \text {; PhD students } 0.7 \% \text {; Graduate BSc, } \\
\text { MSc, not employed } 4.1 \% \text {; Graduate BSc, MSc, employed } 31.4 \% \text {, } \\
\text { Non-student/graduate, not employed } 0.2 \% \text {; Non-student/graduate, employed } \\
0.5 \%\end{array}$ \\
\hline Personal status & Single $41.4 \%$; In a relationship 51.9\%; Married $6.6 \%$ \\
\hline Place of residence & $\begin{array}{l}\text { City } 500.000 \text { inhabitantsp or more } 19 \% \text {; City } 200.000-500.000 \text { inhabitantsp } 39.4 \% \text {; } \\
\text { City } 100.000-200.000 \text { inhabitantsp } 7.1 \% \text {; City, } 50.000-100.000 \text { inhabitantsp } 8.5 \% \text {; } \\
\text { City less than } 50.000 \text { inhabitantsp } 15.6 \% \text {; Countryside, suburban zone } 6.2 \% \text {; } \\
\text { Countryside } 4.3 \%\end{array}$ \\
\hline Housing status & $\begin{array}{l}\text { Own flat/house (without mortgage) } 23.1 \% \text {, Own flat/house (mortgage) } 4.3 \% \text {, } \\
\text { Flat/house owned by family } 29.1 \% \text {, Rented flat } 38.7 \% \text {, Dormitory } 4.8 \%\end{array}$ \\
\hline Household size & $\begin{array}{l}\text { One person } 6.6 \% \text {; Two persons } 41 \% \text {; Three, four or five persons } 48.5 \% \text {; More than } \\
\text { five persons } 3.9 \%\end{array}$ \\
\hline Kids in the household (0-16) & Yes $9.8 \%$; No $90.2 \%$ \\
\hline Monthly income per person & $\begin{array}{l}500 \text { PLN or less } 2.7 \% ; 500-1000 \text { PLN } 8.7 \% \text {; } 1000-1500 \text { PLN } 18.1 \% ; 1500-2000 \text { PLN } \\
20.8 \% ; 2000-3000 \text { PLN } 20.8 \% \text {; } 3000-5000 \text { PLN } 15.3 \% \text {; more than } 5000 \text { PLN } 7.3 \%\end{array}$ \\
\hline
\end{tabular}




\subsection{Data Analysis}

The data gathered in the survey mostly had a nominal or ordinal character.

The participants were asked to express their opinion on a number of statements connected with urban mobility and its development perspectives and various transport modes. Table 2 summarizes the opinions given, which were measured on a Modified Likert Scale from 1 to 7 . The higher the mean score, the more, in general, the participants agree with a given statement.

Table 2. The participants' opinions on urban mobility.

\begin{tabular}{ll}
\hline \multicolumn{1}{c}{ Statement } & Mean Score (Likert Scale-1 to 7) \\
\hline Being eco-friendly is the most important characteristic of a car & 4.90 \\
\hline Caring about the environment and having an eco-friendly car are important & 4.60 \\
\hline I believe cars should be environmentally friendly & 3.65 \\
\hline Cars should be powered by renewable sources of energy & 3.69 \\
\hline Cars should be more durable than they are right now & 4.39 \\
\hline The introduction of Uber and similar applications is a good thing & 4.15 \\
\hline I like the concept of carsharing and renting cars per hour & 3.88 \\
\hline $\begin{array}{l}\text { If a public carrier offered an hourly car rental service, I would use such a } \\
\text { service }\end{array}$ & 2.86 \\
\hline Only no-emission and low-emission vehicles should be allowed in the cities & 2.85 \\
\hline A public city car (rented per hour) is a good solution for modern cities & 3.59 \\
\hline $\begin{array}{l}\text { A bike-sharing system connected with a rapid urban rail system is an effective } \\
\text { solution for public transport users }\end{array}$ & 3.98 \\
\hline \begin{tabular}{l} 
I believe that public city cars could work in Poland \\
\hline I would like the public transport to be more ecology-oriented
\end{tabular} & 3.26 \\
\hline $\begin{array}{l}\text { If there were a city car offered as a part of the public transport system, I would } \\
\text { stop using my own car }\end{array}$ & 3.09 \\
\hline $\begin{array}{l}\text { If there were a ban on private cars in the city centre, I would rather use a } \\
\text { public city car than a bus or a tram }\end{array}$ & 2.08 \\
\hline
\end{tabular}

Overall, the participants agree with the general statements connected with caring about the environment. The respondents believe that cars should be eco-friendly and that they should be more durable than they are right now. In general, the respondents believe that the introduction of Uber and Uber-like services is a good thing, but they seem to show reservation when it comes to public city cars. They do not believe the public city cars to be a good solution for modern cities and declare that they would not use it themselves, especially not as a substitute for their own car. Even more so, if offered no other choice, they would still prefer to use buses and trams to commute to the city centre than a public car. Naturally, this means that they do not believe in the success of public city cars in Poland.

Exploratory factor analysis was then performed, in order to examine whether the statements can be associated with latent dimensions. Factor analysis is used to reduce a large number of partially collinear variables into a smaller number of variables, which represent latent beliefs of the respondents. This allows us to draw more precise conclusions and facilitates further analysis. The varimax rotation was applied in the analysis to make sure that the extracted factors were orthogonal. This makes the interpretation of the data easier. Table 3 shows the results of the factor analysis which allowed us to identify four components (with eigenvalues $>1.0$ ). 
Table 3. Factor analysis_-varimax rotation.

\begin{tabular}{|c|c|c|c|c|}
\hline Statement & Factor 1 & Factor 2 & Factor 3 & Factor 4 \\
\hline Being eco-friendly is the most important characteristic of a car & $0.79 *$ & -0.02 & 0.09 & -0.08 \\
\hline $\begin{array}{l}\text { Caring about the environment and having an eco-friendly car } \\
\text { are important }\end{array}$ & 0.82 & -0.06 & 0.13 & 0.01 \\
\hline I believe cars should be environmentally friendly & 0.83 & 0.18 & 0.01 & -0.04 \\
\hline Cars should be powered by renewable sources of energy & 0.79 & 0.25 & 0.01 & 0.02 \\
\hline Cars should be more durable than they are right now & 0.27 & 0.43 & 0.06 & -0.41 \\
\hline $\begin{array}{l}\text { The introduction of Uber and similar applications is a } \\
\text { good thing }\end{array}$ & -0.02 & 0.80 & 0.09 & 0.03 \\
\hline I like the concept of carsharing and renting cars per hour & 0.11 & 0.68 & 0.40 & 0.12 \\
\hline $\begin{array}{l}\text { If a public carrier offered an hourly car rental service, I would } \\
\text { use such a service }\end{array}$ & 0.08 & 0.23 & 0.78 & 0.10 \\
\hline $\begin{array}{l}\text { Only no-emission and low-emission vehicles should be } \\
\text { allowed in the cities }\end{array}$ & 0.76 & 0.03 & 0.16 & -0.07 \\
\hline $\begin{array}{l}\text { A public city car (rented per hour) is a good solution for } \\
\text { modern cities }\end{array}$ & 0.10 & 0.49 & 0.58 & 0.29 \\
\hline $\begin{array}{l}\text { A bike-sharing system connected with a rapid urban rail } \\
\text { system is an effective solution for public transport users }\end{array}$ & 0.35 & 0.61 & -0.14 & 0.05 \\
\hline I believe that public city cars could work in Poland & -0.02 & 0.16 & 0.11 & 0.82 \\
\hline I would like the public transport to be more ecology-oriented & 0.73 & 0.04 & 0.07 & 0.15 \\
\hline $\begin{array}{l}\text { If there were a city car offered as a part of the public transport } \\
\text { system, I would stop using my own car }\end{array}$ & 0.33 & -0.21 & 0.67 & 0.00 \\
\hline $\begin{array}{l}\text { If there were a ban on private cars in the city centre, I would } \\
\text { rather use a public city car than a bus or a tram }\end{array}$ & -0.07 & 0.15 & 0.58 & -0.44 \\
\hline Eigenvalue & 4.06 & 2.15 & 2.00 & 1.17 \\
\hline
\end{tabular}

* Bold values indicate factor loadings over 0.5.

Factor loadings higher than 0.5 have been highlighted in the table. The pattern of the factor loadings indicates that they can be associated with the necessity for environmentally friendly transport, the shared mobility solutions, the city car systems and their future in Poland. The statements, which have the highest factor loadings in the first factor, reflect the respondent's belief that the cars should be environmentally friendly, that they should be based on renewable sources of energy but also that the public transport should be more ecology-oriented. Therefore, the first factor can be said to reflect the strength of the ecology-oriented approach of the respondent.

The three statements, which are significant in the second factor, reflect the respondent's attitude towards different types of shared mobility concepts, i.e., the carsharing, the bike-sharing (in combination with public transport) and Uber. Although there is some debate, whether Uber should be treated as a shared mobility solution, given that nothing is shared per se [48]. Still, it is associated with carsharing by many people.

The third factor is very specifically connected with the attitude towards the concept of a public city car, which could be rented per hour. Apparently, it is considered by the respondents to be a different concept from the other shared mobility solutions, which were visible in factor 2 . The four statements with the high factor loadings in the factor show if the respondent would be willing to use such a service, in substitution of the public transport services or a private car. The factor is also strongly correlated with the overall assessment of the concept of the public city car. Interestingly enough, this factor does not reflect the belief in the success of the public city car concept in Poland, which is strongly associated, on its own, with the fourth factor. This means that the attitude towards the concepts of the system itself shows a different pattern that the belief in the potential success of the system in Poland. 


\section{Results}

In order to analyse the differences in the four attitudes identified through the factor analysis, we have performed an analysis of variance (ANOVA) with the four factors as the dependent variables. Table 4 shows the differences between groups in regards to their attitude towards the importance of the ecology-oriented approach to transport (Factor 1), shared mobility systems (Factor 2), city car systems (Factor 3) and their future in Poland (Factor 4).

Table 4. ANOVA—differences in attitudes.

\begin{tabular}{cccccccccc}
\hline & \multicolumn{2}{c}{ Factor 1 } & \multicolumn{2}{c}{ Factor 2 } & \multicolumn{2}{c}{ Factor 3 } & \multicolumn{2}{c}{ Factor 4 } \\
\hline Effect & $\boldsymbol{F}$ & $\boldsymbol{p}$ & $\boldsymbol{F}$ & $\boldsymbol{p}$ & $\boldsymbol{F}$ & $\boldsymbol{p}$ & $\boldsymbol{F}$ & $\boldsymbol{p}$ \\
\hline Decade of birth & 6.68 & 0.01 & 0.23 & 0.63 & 0.02 & 0.88 & 0.44 & 0.51 \\
Driver license & 7.91 & 0.00 & 0.99 & 0.37 & 3.27 & 0.04 & 0.83 & 0.44 \\
Sex & 22.53 & 0.00 & 0.58 & 0.45 & 2.81 & 0.10 & 0.95 & 0.33 \\
Own car & 1.15 & 0.33 & 1.94 & 0.12 & 0.44 & 0.73 & 0.29 & 0.83 \\
Main means of transport & 0.37 & 0.69 & 0.66 & 0.52 & 0.44 & 0.65 & 2.17 & 0.12 \\
Using PT & 2.76 & 0.02 & 0.75 & 0.59 & 1.99 & 0.08 & 1.03 & 0.40 \\
Personal status & 0.55 & 0.58 & 0.40 & 0.67 & 0.14 & 0.87 & 3.44 & 0.03 \\
Housing status & 0.31 & 0.87 & 1.71 & 0.15 & 0.59 & 0.67 & 1.53 & 0.19 \\
Place of residence & 0.76 & 0.61 & 2.49 & 0.02 & 0.91 & 0.49 & 1.34 & 0.24 \\
Student/employment status & 0.38 & 0.89 & 4.48 & 0.00 & 0.56 & 0.77 & 1.07 & 0.38 \\
Household size & 1.44 & 0.23 & 1.34 & 0.26 & 0.94 & 0.42 & 2.71 & 0.05 \\
Kids in the household (0-16) & 0.95 & 0.33 & 0.82 & 0.37 & 2.64 & 0.11 & 0.21 & 0.65 \\
Monthly income per person & 1.55 & 0.15 & 0.80 & 0.59 & 1.10 & 0.36 & 0.55 & 0.80 \\
\hline
\end{tabular}

The analysis of variance revealed significant differences in the ecology-oriented approach between people born in different decades, between men and women and between people with driving licences and people without them. A post-hoc analysis shows that on average, people born in the 80s are more ecology-oriented than people born in the 90s. Women are definitely more ecology-oriented than men. People without a driver's licence declare themselves to be more ecology-oriented than those who have one. Interestingly enough, there is no statistically significant difference between people in regards to their motorisation status and their default mode of transport. However, the frequency of the use of public transport is correlated with the ecology-oriented approach. People who use public transport at least once a week are statistically more ecology-oriented than people who use it rarely or not at all. No differences were found in regards to other groups.

The attitude towards shared mobility solutions varies depending on the place of residence and the employment status. Residents of large cities (200 to 500 thousand inhabitants and more than 500 thousand inhabitants) are significantly more keen on shared mobility solutions. Obviously, they are also more familiar with them, which means that they have had a higher chance to benefit from them. Although there are bike-sharing systems in a few cities in Poland, which are smaller than that, they are still very rare, whereas they are present in almost all of the bigger cities. Interestingly enough, the year of birth is not correlated with the attitude towards shared mobility.

The factor analysis has shown that it is a concept the public city car, which is separate from carsharing and bike-sharing. Naturally then, the attitude towards the concept is also affected by different factors. Based on the results of the ANOVA only having driving licence affects this phenomenon. Contrary to the expectations, people without driver's licences are more interested in the concept than the people who have them. Possibly the lack of driving experience results in a more positive perception of the concept of the public city car.

The factor analysis has proven that the attitude towards the concept of the public city cars is separate from the belief in their success in Poland. This is further proven by the results of ANOVA with factor 4 as the dependent variable. Unlike the previous factors, this belief seems not to be affected by transportation status but instead by the personal status and the household size. People in an informal relationship are generally more optimistic when it comes to city car concept than people who are 
married and people who are single. In addition, people who live on their own are less optimistic than people who live at least with one other person in the same household.

\section{Discussion}

Despite many literature items referring to the problem of shaping the mobility of young adults, they do not concern strictly the attitudes of young adults regarding sustainable transport. In addition, usually Generation $Y$ is treated as one cohort [38,49], but as shown in the study, there are significant differences in the attitudes of older people (cohort born in 1981-1990) and younger (born in 1991-1999) [39,44] in regards to the ecology-oriented approach to transport. Surprisingly, it was denied that younger people are more eco-friendly than older ones. Usually, in the literature of the subject, this relationship was described inversely, seeing a less ecology-oriented attitude among older representatives of the generation [6], mainly because of their life-stage [29,35]. Having children and being engaged in professional work were seen as important determinants of less ecology-oriented mobility attitudes [36]. In turn, life-stage can be associated with Factor 4 and ANOVA results for this factor, because people in informal relationships and living with at least one person have been more positive about the development of public car concepts in Poland.

It has been possible to confirm the thesis that gender is affecting the environmental attitudes of young adults. Almost all of the identified papers that examined differences between gender representatives indicated that women declared more eco-friendly attitudes than men $[24,50,51]$. Another result of this identified in the literature concerns the attitudes of drivers and people without a driving license. It is obvious that people with a driving license will have a greater propensity to use a car-the least ecology-oriented means of transport [15,35]. Non-driving people, in turn, choose a different mode of transport; they may also have a greater inclination to multimodal mobility patterns when travelling around the city [36,52]. Most of them use public transport, so they also present an ecology-oriented attitude $[18,44,53]$. It is also possible to deduce, what should be examined in future research, whether multimodal attitudes can also be presented by drivers using, for example, park and ride solutions in urban areas [2,54].

Young adults positively referred to the launch of new mobility services, including Uber and similar solutions, also referred to as Mobility-as-a-Service $[45,48,55,56]$. The growing popularity of MaaS providers in urban areas may contribute to changes in mobility patterns of young people, as it will require further research in the coming years. People living in big cities rated these solutions higher than residents of smaller cities [57]. The reason for this result may be greater access to carsharing and bike-sharing services in large cities, where these solutions usually appear faster than in smaller ones.

In contrast, respondents presented a different opinion in relation to using the public car. This concept is new on the mobility market and successfully used, but in a few cities [58,59]. In Poland, it has not been implemented. Perhaps the lack of knowledge about similar solutions and lack of experience in using them caused that the respondents were not favourable to this concept. However, people without a license were more interested in using such solutions, which may be related to their greater tendency to use public transport and multimodal city transport.

\section{Conclusions}

This study fills the identified literature gap regarding a thorough examination of the environmental attitudes of young adults in the field of urban transport. So far, dozens of studies have appeared that identify individual elements of the $Y$ generation mobility patterns, but do not fully treat the concept of eco-friendliness of young adults $[6,60]$, being a part of environmental sustainable mobility. This article is the first to examine the attitudes of the Generation $Y$ in Poland, referring them only to moving in urban and suburban areas. The remaining ones that have been identified also describe the mobility of the same age group, also in relation to mobility, but typically related to relocation associated with a change of job $[61,62]$. Both of these areas are located in an area called terrestrial mobility, but they differ in the purposes of travellers and length of the journey. 
Several implications of this study should be mentioned. Firstly, the ecology-oriented mobility attitudes of Polish Generation Y were examined. The added value of this analysis was the investigation of the opinions about the sharing-economy solutions within the mobility market area-shared mobility and public city cars. Therefore, this paper provides the insights into the mobility patterns of Polish young adults in the area of sustainable mobility. Secondly, it gives the opportunity for decision makers to verify and adjust their services to cater to the needs, opinions and behaviour of their customers not only in the analysed national market, but in the whole region. Those include public transport operators and mobility service providers, but also the local authorities, creating sustainable transport policy in cities. Thirdly, this study presents a huge value for the broader audience, especially researchers specialised in the area of urban logistics, economic geography and public transport to compare their research results.

The authors are aware that this research has a few limitations. Firstly, using semi-random sampling study indicates only some possible results in the studied population, and the level of occurrence of particular environmental attitudes may significantly differ from that in the studied sample. Secondly, this study was more short-term-oriented and examined only the currently-declared attitudes of $Y$ generation. A longitudinal research focusing on the changes in mobility in connection with the life cycle of young adults could result in a model of causal relations between attitudes, lifestyle and transport behaviour. There is always a risk of obtaining different research results However, the authors have made every effort to minimise the risks and present the results in the best possible way.

Despite the mentioned limitations, the described research results are promising and provide many future research possibilities, and can also serve as a basis for further studies. They can be used by many stakeholders to review their strategy and verify the offer of mobility services.

Further research should be conducted to obtain more data on Generation Y mobility attitudes (including the environmental ones), especially, if possible, with the use of random sampling methods. A more refined conceptualisation of the determinants of ecology-oriented mobility choices of young adults should be carried out, as the comparison of Generation Y environmental attitudes with those declared by the older generations. In addition, a longitudinal research should be made in order to track the mobility patterns of $Y$ generation. It may have a significant meaning for creating new services in the field of public and private transport, mono-and multimodal transport in urban and suburban areas [57]. These issues in the area of generations' mobility should be addressed in future theoretical and empirical research.

Author Contributions: Conceptualization, M.S. and A.S.-J.; Data curation, M.S. and A.S.-J.; Formal analysis, M.S.; Investigation, M.S. and A.S.-J.; Methodology, M.S. and A.S.-J.; Project administration, A.S.-J.; Software, M.S.; Validation, M.S. and A.S.-J.; Visualization, A.S.-J.; Writing—original draft, M.S. and A.S.-J.; Writing—review \& editing, M.S. and A.S.-J.

Funding: This research received no external funding.

Conflicts of Interest: The authors declare no conflict of interest.

\section{References}

1. Okraszewska, R.; Romanowska, A.; Wołek, M.; Oskarbski, J.; Birr, K.; Jamroz, K. Integration of a multilevel transport system model into sustainable Urban mobility planning. Sustainability 2018, 10, 479. [CrossRef]

2. Burian, J.; Zajícková, L.; Ivan, I.; Macku, K. Attitudes and Motivation to Use Public or Individual Transport: A Case Study of Two Middle-Sized Cities. Soc. Sci. 2018, 7, 83. [CrossRef]

3. Schliwa, G.; Armitage, R.; Aziz, S.; Evans, J.; Rhoades, J. Sustainable city logistics - Making cargo cycles viable for urban freight transport. Res. Transp. Bus. Manag. 2015, 15, 50-57. [CrossRef]

4. Fossheim, K.; Andersen, J. Plan for sustainable urban logistics-comparing between Scandinavian and UK practices. Eur. Transp. Res. Rev. 2017, 9. [CrossRef]

5. De Freitas Miranda, H.; Rodrigues da Silva, A.N. Benchmarking sustainable urban mobility: The case of Curitiba, Brazil. Transp. Policy 2012, 21, 141-151. [CrossRef] 
6. Simons, D.; Clarys, P.; De Bourdeaudhuij, I.; de Geus, B.; Vandelanotte, C.; Deforche, B. Why do young adults choose different transport modes? A focus group study. Transp. Policy 2014, 36, 151-159. [CrossRef]

7. Buldeo Rai, H.; Verlinde, S.; Macharis, C. Shipping outside the box. Environmental impact and stakeholder analysis of a crowd logistics platform in Belgium. J. Clean. Prod. 2018, 202, 806-816. [CrossRef]

8. Vakulenko, Y.; Hellström, D.; Hjort, K. What's in the parcel locker? Exploring customer value in e-commerce last mile delivery. J. Bus. Res. 2018, 88, 421-427. [CrossRef]

9. Zenezini, G.; van Duin, J.H.R.; Tavasszy, L.; De Marco, A. Stakeholders' Roles for Business Modeling in a City Logistics Ecosystem: Towards a Conceptual Model. In City Logistics 2: Modeling and Planning Initiatives; Taniguchi, E., Thompson, R.G., Eds.; ISTE Ltd.: Arlington, VA, USA, 2018; pp. 39-58. ISBN 9781786302069.

10. Lindenau, M.; Böhler-Baedeker, S. Citizen and Stakeholder Involvement: A Precondition for Sustainable Urban Mobility. Transp. Res. Procedia 2014, 4, 347-360. [CrossRef]

11. Robertson, K. Comparison of the EU's Sustainable Urban Mobility Plan (SUMP) and the Swedish Planning Support Transport for an Attractive city (TRAST); Swedish National Road and Transport Research Institute (VTI): Linköping, Sweden, 2015; ISBN 0000000310.

12. Bos, R.; Temme, R. A Roadmap towards Sustainable Mobility in Breda. Transp. Res. Procedia 2014, 4, $103-115$. [CrossRef]

13. Diez, J.M.; Lopez-Lambas, M.E.; Gonzalo, H.; Rojo, M.; Garcia-Martinez, A. Methodology for assessing the cost effectiveness of Sustainable Urban Mobility Plans (SUMPs). The case of the city of Burgos. J. Transp. Geogr. 2018, 68, 22-30. [CrossRef]

14. Ribeiro, J.M.P.; Bocasanta, S.L.; Ávila, B.O.; Magtoto, M.; Jonck, A.V.; Gabriel, G.M.; de Andrade Guerra, J.B.S.O. The adoption of strategies for sustainable cities: A comparative study between Seattle and Florianopolis legislation for energy and water efficiency in buildings. J. Clean. Prod. 2018, 197, 366-378. [CrossRef]

15. Suchanek, M.; Pawłowska, J. Effects of Transport Behaviour on Public Health: A Study on the Students in the Tricity Area. In New Research Trends in Transport Sustainability and Innovation. TranSopot Conference; Suchanek, M., Ed.; Springer: Cham, Switzerland, 2018; pp. 28-36.

16. Marge, R.; Iovan, S.; Iovan, A. Sustainable Mobility for Public Transport. In Annals of the 'Constantin Brâncuşi' University of Targu Jiu: Letters and Social Sciences Series; University Constantin Brancusi of Targu Jiu: Targu Jiu, Romania, 2017; pp. 193-197.

17. Ding, G.K.C. Developing a multicriteria approach for the measurement of sustainable performance. Build. Res. Inf. 2005, 33, 3-16. [CrossRef]

18. Becker, H.; Ciari, F.; Axhausen, K.W. Comparing car-sharing schemes in Switzerland: User groups and usage patterns. Transp. Res. Part A Policy Pract. 2017, 97, 17-29. [CrossRef]

19. Zavada, J.B.; Abramović, B.; Šipuš, D. A Strategic Model of Sustainable Mobility in the city of Zagreb and its Surrounding Area. Int. J. Traffic Transp. Eng. 2017, 7, 430-442.

20. Chakhtoura, C.; Pojani, D. Indicator-based evaluation of sustainable transport plans: A framework for Paris and other large cities. Transp. Policy 2016, 50, 15-28. [CrossRef]

21. Sdoukopoulos, E.; Kose, P.; Gal-Tzur, A.; Mezghani, M.; Boile, M.; Sheety, E.; Mitropoulos, L. Assessment of Urban Mobility Needs, Gaps and Priorities in Mediterranean Partner Countries. Transp. Res. Procedia 2016, 14, 1211-1220. [CrossRef]

22. Tafidis, P.; Sdoukopoulos, A.; Pitsiava-Latinopoulou, M. Sustainable urban mobility indicators: Policy versus practice in the case of Greek cities. Transp. Res. Procedia 2017, 24, 304-312. [CrossRef]

23. Tomanek, R. Free-fare public transport in the concept of sustainable urban mobility. Transp. Probl. 2017, $12,95-105$.

24. Tilley, S.; Houston, D. The gender turnaround: Young women now travelling more than young men. J. Transp. Geogr. 2016, 54, 349-358. [CrossRef]

25. Hopkins, D. Can environmental awareness explain declining preference for car-based mobility amongst generation Y? A qualitative examination of learn to drive behaviours. Transp. Res. Part A Policy Pract. 2016, 94, 149-163. [CrossRef]

26. Nash, S.; Mitra, R. Travel Behaviour and Residential Location of the Millennials: A Case Study of Post-Secondary Students from Four Toronto-Area Universities; Centre for Urban Research and Land Development: Toronto, ON, Canada, 2018. 
27. Wittwer, R. Cluster-analytical-creation of a Typology of Young Adults'Travel Behavior in Germany. Procedia Soc. Behav. Sci. 2014, 160, 64-73. [CrossRef]

28. Sigurdardottir, S.B.; Møller, M.; Teasdale, T.W. DTU Transport; Technical University of Denmark. Kongens: Lyngby, Denmark, 2013.

29. Circella, G.; Fulton, L.; Alemi, F.; Berliner, R.M.; Tiedeman, K.; Mokhtarian, P.L.; Handy, S. What Affects Millennials 'Mobility? PART I: Investigating the Environmental Concerns, Lifestyles, Mobility-Related Attitudes and Adoption of Technology of Young Adults in California; University of California: Davis, CA, USA, 2016.

30. Delbosc, A.; Nakanishi, H. A life course perspective on the travel of Australian millennials. Transp. Res. Part A Policy Pract. 2017, 104, 319-336. [CrossRef]

31. Simons, D.; Clarys, P.; De Bourdeaudhuij, I.; de Geus, B.; Vandelanotte, C.; Deforche, B.; Kuhnimhof, T.; Buehler, R.; Wirtz, M.; Kalinowska, D.; et al. Travel trends among young adults in Germany: Increasing multimodality and declining car use for men. J. Transp. Geogr. 2014, 36, 229-235.

32. Döring, L.; Albrecht, J.; Scheiner, J.; Holz-Rau, C. Mobility Biographies in Three Generations-Socialization Effects on Commute Mode Choice. Transp. Res. Procedia 2014, 1, 165-176. [CrossRef]

33. Haustein, S.; Klöckner, C.A.; Blöbaum, A. Car use of young adults: The role of travel socialization. Transp. Res. Part F Psychol. Behav. 2009, 12, 168-178. [CrossRef]

34. Dewalska-Opitek, A. Transport System Telematics Generation Y Consumer preferences and mobility choices-An empirical approach. Arch. Transp. Syst. Telemat. 2017, 10, 17-23.

35. Newbold, K.B.; Scott, D.M. Driving over the life course: The automobility of Canada's Millennial, Generation X, Baby Boomer and Greatest Generations. Travel Behav. Soc. 2017, 6, 57-63. [CrossRef]

36. Circella, G.; Berliner, R.M.; Lee, Y.; Handy, S.L.; Alemi, F.; Tiedeman, K.; Fulton, L.; Mokhtarian, P.L. The Multimodal Behavior of Millennials: Exploring Differences in Travel Choices between Young Adults and Gen Xers in California; Institute of Transportation Studies: Davis, CA, USA, 2017.

37. Lopez-Carreiro, I.; Monzon, A. Evaluating cycling behaviour of Millennials in Vitoria-Gasteiz. Transp. Res. Procedia 2018, 33, 171-178. [CrossRef]

38. McDonald, N.C. Are millennials really the "go-Nowhere" Generation? J. Am. Plan. Assoc. 2015, 81, 90-103. [CrossRef]

39. Vukic, M.; Kuzmanovic, M.; Kostic Stankovic, M. Understanding the Heterogeneity of Generation Y's Preferences for Travelling: A Conjoint Analysis Approach. Int. J. Tour. Res. 2015, 17, 482-491. [CrossRef]

40. Stojanová, H.; Tomšík, P.; Tesařová, E. The Approach To the Work Mobility in Generation Y—Enthusiasm for Change-Enthusiasm for Change. Hum. Resour. Manag. Ergon. 2015, IX, 83-96.

41. Sziva, I.; Zoltay, R.A. How to catch the critical Generation?-The interests, and travel needs of Generation $Y$ during cultural travels. In Proceedings of the TCL2016 Conference, Budapest, Hungary, 12-16 June 2016; pp. 554-564.

42. Raunio, J.M. Understanding the Travel Behavior of Generation Y; Mittuniversitetet: Sundsvall, Sweden, 2014.

43. Goodwin, P. Three Views on Peak Car. World Transp. Policy Pract. 2012, 17, 8-17.

44. Lavieri, P.S.; Garikapati, V.M.; Bhat, C.R.; Pendyala, R.M. Investigation of Heterogeneity in Vehicle Ownership and Usage for the Millennial Generation. Transp. Res. Rec. J. Transp. Res. Board 2017, 2664, 91-99. [CrossRef]

45. Szmelter, A.; Woźniak, H. New Mobility Behaviours and Their Impact on Creation of New Business Models. Torun Bus. Rev. 2015, 15, 79-95.

46. Garikapati, V.M.; Pendyala, R.M.; Morris, E.A.; Mokhtarian, P.L.; McDonald, N.C. Activity Patterns, Time Use, and Travel of Millennials: A Generation in Transition? Transp. Rev. 2016, 36, 558-584. [CrossRef]

47. Ralph, K.; Voulgaris, C.T.; Taylor, B.D.; Blumenberg, E.; Brown, A.E. Millennials, built form, and travel insights from a nationwide typology of US neighborhoods. J. Transp. Geogr. 2016, 57, 218-226. [CrossRef]

48. Pick, F.; Dreher, J. Sustaining hierarchy-Uber isn't sharing. Kings Review, 11 May 2015.

49. Hopkins, D.; Stephenson, J. Generation Y mobilities through the lens of energy cultures: A preliminary exploration of mobility cultures. J. Transp. Geogr. 2014, 38, 88-91. [CrossRef]

50. Fenton, P.; Gustafsson, S. Contesting sustainability in urban transport-Perspectives from a Swedish town. Nat. Resour. Forum 2015, 39, 15-26. [CrossRef]

51. Nuzir, F.; Dewancker, B.J. Redefining place for walking: A Literature review and key-elements conception. Theor. Empiracal Res. Urban Manag. 2016, 11, 59-76.

52. Sandkuhl, K.; Lin, F.; Shilov, N.; Smirnov, A.; Tarasov, V.; Krizhanovsky, A. Logistics-as-a-service: Ontology-based architecture and approach. Investig. Oper. 2013, 34, 188-194. 
53. Li, Z.; Hensher, D. Crowding in Public Transport: A Review of Objective and Subjective Measures. J. Public Transp. 2015, 16, 107-134. [CrossRef]

54. Zambon, I. Exploring Student Mobility: University Flows and the Territorial Structure in Viterbo. Urban Sci. 2019, 3, 47. [CrossRef]

55. Finck, M.; Ranchordas, S. Sharing and the city. Vanderbilt J. Transnatl. Law 2016, 49, 1299-1369. [CrossRef]

56. Schor, J. Debating The Sharing Economy. J. Self-Gov. Manag. Econ. 2017, 4, 7.

57. Ambrosino, G.; Nelson, J.D.; Boero, M.; Pettinelli, I. Enabling intermodal urban transport through complementary services: From Flexible Mobility Services to the Shared Use Mobility Agency: Workshop 4. Developing inter-modal transport systems. Res. Transp. Econ. 2016, 59, 179-184. [CrossRef]

58. Cox, W. Mobility and Prosperity in the City of the Future. Available online: https://www.macdonaldlaurier. $\mathrm{ca} /$ files/pdf/Mobility-and-Prosperity-in-the-City-of-the-Future-Commentary-May-2012.pdf (accessed on 8 June 2019).

59. Manderscheid, K. The Movement Problem, the Car and Future Mobility Regimes: Automobility as Dispositif and Mode of Regulation. Mobilities 2014, 9, 604-626. [CrossRef]

60. de Abreu e Silva, J.; de Oña, J.; Gasparovic, S. The relation between travel behaviour, ICT usage and social networks. the design of a web based survey. Transp. Res. Procedia 2017, 24, 515-522. [CrossRef]

61. Abdul-Rahman, H.; Wang, C.; Wood, L.C.; Ebrahimi, M. Integrating and ranking sustainability criteria for housing. Proc. Inst. Civ. Eng. Eng. Sustain. 2016, 169, 3-30. [CrossRef]

62. Howley, P.; Scott, M.; Redmond, D. An examination of residential preferences for less sustainable housing: Exploring future mobility among Dublin central city residents. Cities 2009, 26, 1-8. [CrossRef]

(C) 2019 by the authors. Licensee MDPI, Basel, Switzerland. This article is an open access article distributed under the terms and conditions of the Creative Commons Attribution (CC BY) license (http://creativecommons.org/licenses/by/4.0/). 